\title{
Clio
}

Women, Gender, History

$40 \mid 2014$

Making Gender with Things

\section{Objects of gender and the gender of objects in French ethnology and sociology}

Objets du genre et genre des objets en ethnologie et sociologie françaises

\section{Anne Monjaret}

Translator. Regan Kramer

\section{OpenEdition}

\section{Journals}

\section{Electronic version}

URL: http://journals.openedition.org/cliowgh/714

DOI: $10.4000 /$ cliowgh.714

ISSN: 2554-3822

Publisher

Belin

\section{Electronic reference}

Anne Monjaret, « Objects of gender and the gender of objects in French ethnology and sociology », Clio [Online], 40 | 2014, Online since 15 April 2015, connection on 19 April 2019. URL : http:// journals.openedition.org/cliowgh/714; DOI : 10.4000/cliowgh.714 


\section{Current research}

\section{Objects of gender and the gender of objects in French ethnology and sociology}

In France, approaches to material and technical culture in traditional and contemporary societies, both here and elsewhere, typically belong to the field of ethnology, which has always seen objects as witnesses to societies, offering access to their social, symbolic and, therefore, gendered uses. Analysing everyday or ritual practices continues, as it has in the past, to lead ethnologists, joined in this by sociologists, to observe the ways in which roles are divided between men and women - in other words, to examine the construction of gendered identities in terms of material culture, without that becoming a subject of research in and of itself.

Paola Tabet's ground-breaking 1979 text, "Hands, Tools, Weapons", most certainly contributed both to a broader realization of the advantages and relevance of these considerations, and to going beyond them, by choosing a critical reading of existing studies and a rereading of social facts. Studying the "tools that men and women use"1 in hunter-gatherer societies, Tabet, an anthropologist, challenged the idea of complementarity or reciprocity in the division of labor between the sexes, "even in supposedly egalitarian societies." 2 She showed how

Tabet 1979: 5 .

2 Tabet 1979: 10. 
males dominate females by excluding them from technical resources. She therefore called for an anthropology "not of men, but of humankind". 3

Thus we can see that examining the relationship between gender and objects is nothing new. Thanks to gender studies, which are booming in France, this examination has become more explicit, and been renewed and developed over time. In conjunction with the ethnology of material culture and the sociology of everyday life, they have experienced a renewal of interest over the past few years.

Gendered expressions of material culture have become an object of study in their own right. Although works on the subject in French are still relatively few and far between, the publication of several books addressing the subject directly is significant enough in these terms to be worth mentioning. In 2005, Marie-Pierre Julien and Céline Rosselin proposed, in a volume in the "Repères" ("Bearings") collection devoted to material culture, a brief summary entitled "gendered matter(s)." Based on both classic and contemporary writers, they address the issue of "bodily techniques", as one that reveals attitudes specific to women and men, and the issue of objects as attributes for distinguishing the sexes. They focus on the idea that the construction of gender is "supported on a daily basis by material culture $(. .$.$) caught within networks of actions on other actions". { }^{4}$ More recently, the multiple-author book Les Objets ont-ils un genre? ("Do Objects Have a Gender?"), edited by the anthropologists Élisabeth Anstett and Marie-Luce Gélard, makes this field a subject of study in and of itself. Divided into three parts, "Masculine?", "Feminine?" and "Neutral?", and using a range of cultural and social examples, this collection examines both what gender does to objects and what objects to do gender. ${ }^{5}$ The publication, as this overview of current research goes to press, of Georges-Claude Guilbert's book Le Genre des objets [The Gender of Objects] is proof of the burgeoning interest in the subject amongst academics. ${ }^{6}$ By the same token, two

\footnotetext{
3 Tabet 1979: 51.

4 Julien \& Rosselin 2005: 94

5 Anstett \& Gélard 2012.

6 Guilbert 2014.
} 
exhibits: "Morceaux exquis" ("Exquisite Morsels" a play on the Surrealist parlor game Cadavre exquis, "Exquisite Corpse", aka "picture consequences") in Paris in 2011, and "Au bazar du genre" ("At the Gender Bazaar"), in Marseille in 2013, portray the subject through the prism of "the body in popular cultures", for the former, ${ }^{7}$ and through the many and contrasting expressions of femininity and masculinity in the Mediterranean region ${ }^{8}$ for the latter. Objects are exhibited in order to express gender and the complexity of understanding it in social terms, giving voice to all genders.

Thus this overview of current research dedicated to gender and objects is fortunate in its timing. Riding the wave of ethnological and other, more sociological studies, it is based on a selection of French publications - both books and articles, from the last 15 years, (20002014). It does not aim to be an exhaustive presentation of studies touching on the topic, but rather an interpretation of the way in which the different authors address it.

Studying the corpus brings out five points of analytical entry: "socialization" (or transmission), "ritualization" (or symbolization), "technification" (or everyday life), "merchandising" (or consumerism) and "museumification" (or entering the cultural heritage): these various social dynamics all contribute to making the analysis of objects and gender intelligible.

\section{Socialization: learning one's gender through objects}

Over the past 15 years, objects have acquired a prominent place in ethnological and sociological research that is focused on youth - from childhood to adulthood, via adolescence ${ }^{9}-$ in western society. Objects offer researchers a way of grasping how individuals - both girls and boys - do (or do not) learn and reproduce gendered and

7 Boëtsch \& Tamarozzi 2011.

8 Chevallier et al. 2013.

9 It should be noted that most of the research was carried out, for the sake of simplicity perhaps, in educational institutions - day-care centers, nursery schools, primary schools, middle and high schools, colleges and universities - rather than in family structures, even if they are not entirely absent. These different institutions identify ages of life. 
sexual differentiation, and, therefore, the division of social roles. Socialization depends on objects.

Toys and games have caught social-science researchers' attention because they contribute to that education. ${ }^{10}$ From earliest childhood, objects offer a way to observe gendered constructions. The sociologist Geneviève Cresson, for example, shows how, in day-care centers, imitation is encouraged through play; girls are given dolls and prompted to care about their looks; boys get trucks and freedom of movement. Starting school does not reverse that dynamic. Julie Delalande's ethnographic research, ${ }^{11}$ carried out in nursery- and primary-school playgrounds in France, confirms this state of affairs. Games, and therefore toys, which are categorized as feminine, masculine or neutral, encourage children, particularly boys, to conform to stereotypes. ${ }^{12}$ Arriving in middle school (at about age 11) doesn't change the schema either. Dominique Pasquier, a sociologist who has studied teenagers' video-game habits, has detected a "reinforcement of sex identities" in collective or inter-personal game play. ${ }^{13}$ Games have a gender, and each gender has its games. ${ }^{14}$

School supplies (pencils, erasers, pencil cases - very popular in France - book bags, etc.) are among the objects that follow children throughout their school lives). Laurence Faure-Rouesnel, a sociologist who studied their social and gendered uses, noticed that girls' school supplies are more organized than boys. "Pencil cases are to girls what pockets are to boys."15

10 Among others: Cresson 2010; Delalande 2001, 2003; Ruel-Traquet 2010; Pasquier 2010.

11 Among others: Delalande 2001, 2003.

12 Ruel-Traquet 2010.

13 Pasquier 2010: 97.

14 Regarding video games and other technological items, mobile phones have done nothing to overturn the habits of teens or adults, on the contrary, it has reinforced clichés: Quéré \& Smoreda 2000 on "The sex of the telephone". The type of camera also distinguishes the sexes: complexity for men, simplicity for women. The advent of the digital era hasn't done much to alter sex distinctions between practices or their gender assignment. On family practices, Jonas 2010. On intra-family transmission, see Sylvie Octobre 2010.

15 Faure-Rouesnel 2001: 504. 
Clothes, be they party or everyday, also allow us to consider gender. Analysing how they are worn, from day-care up, informs us about the gendered staging of appearance. Learning the sexes' dress codes seems to persuade children not to stand out. Geneviève Cresson has observed that, in day-care centers, rather than the gender-reversal play that is popular with adults, Carnival reaffirms gendered identification. Girls are more likely to be dressed up as angels or princesses, while boys have a wider range of costumes. ${ }^{16}$ Society imposes its codes. For instance, in some countries, like 1980s Russia, which Élisabeth Anstett studied, uniform smocks are still mandatory at school. An industrialized object designed for widespread distribution, female pupils' uniforms contribute to the production and state control of gendered identities. Her study contributed to correlating the fields of material culture and gender with the field of policy, in this case, Soviet policy. Uniforms are all the more important to the nation in that they contribute to creating a feminine model, and above all, they make that model's norms and values visible to all. ${ }^{17}$ The individual is shaped by the nation. Elsewhere, individuals may retain greater leeway. That is the case amongst the [French] middle-schoolers studied by sociologist Aurélia Mardon. According to her, while gender diktats and social class affect clothing styles, they are not the only contributing factors. Building individual reputations amongst peers is another one; it offers a way to get around school and parental norms. ${ }^{18}$ All of these outcomes bolster the permeation of our societies by gender stereotyping.

It can happen, however, that objects' gender categorization is overturned through uses that challenge traditional models. The ethnologist Federica Tamarozzi studied 1960s and 1980s Italy, at a time of unprecedented expansion of the middle class and "petite bourgeoisie". Out of the range of toys on offer for children, some of the ones connected to cooking, like the "Dolce Forno" ("My Little Oven"), were aimed - surprisingly, as the author highlights - at both boys and girls. A cookbook (Manuele di Nonna Papera) which was

16 Cresson 2010: 27.

17 Anstett 2012.

18 Mardon 2010. 
presumably written for little girls, actually attracted quite a few boys, becoming a case in point. ${ }^{19}$ According to Federica Tamarozzi, those childhood experiences had a real impact on that generation when they became adults. Sylvie Octobre, on the other hand, believes that tolerance for gender transgression is still relative: Boys' "feminization" is seen as a much more serious social risk than girls' "masculinization". 20 Despite these exceptions, jumping to broad conclusions that would contradict feminist critiques should be avoided: the transmission of traditional models still has tremendous impact in our societies; both objects and/or practices are highly differentiated by sex.

\section{Ritualization: a symbolic reification with one's future at stake}

An approach based on rituals, the classic terrain of ethnology, also allows for an analysis of the gender-object relationship. Rites mark a passage from one condition to another, one status to another. Thus the objects deployed in these ceremonies provide precious clues. Among the publications consulted, there is a clear preponderance of studies of wedding rituals, as seen from a feminine perspective.

Anne Monjaret and Catherine Pugeault, respectively an ethnologist and a sociologist, have studied the phenomenon of single-sex prewedding parties for the future bride or groom in France [known in the UK as stag and hen parties, in the US as bachelor and bachelorette parties]. They highlight the role of symbolic attributes in this ritual, which prepares the guest of honor for married and/or family life. They show how gender distinctions operate, starting with the separation of the male and female ceremonies. The objects featured are there to scramble and/or exaggerate sex roles. Men, for example, dress up as kings or wolves, or adopt the appearance of a gay cop. "In this instance, the virility expressed reflects homosexual style,' rather than the heterosexual model that presumably concerns the young man being fêted." 21 Women play up their sexuality: mini-

\footnotetext{
19 Tamarozzi 2012.

20 Octobre 2010: 72.

21 Monjaret \& Pugeault 2012: 14.
} 
skirts, panther-print stockings, overdone make-up, etc. The sex-toys they get as presents would seem to be unequivocally explicit on that score: "furry handcuffs," "jolly pecker wind-up toys," etc. By the same token, the jokey challenges or tasks assigned to the future bride or groom refer to sexuality: selling condoms to young men in the street, for example, is also a reminder that sexual practices should be controlled and mutually respectful. In this way, although the ritual authorizes certain excesses, the goal is to ease the spouses into their formatted roles. The fun and games are aimed at helping them acquire their new gendered roles. ${ }^{22}$

Despite their semblance of wildness, these ritual-related-objects are actually there to reinforce each sex's specific role. Hence the interest for observers in focusing not on any single object, but on a series of objects, around which symbolic, social and cultural coherence can be woven.

Marie-Luce Gélard proposes to do exactly that by studying the role of objects, particularly the bride's (jewelry, tents, etc.) in collective weddings in Morocco. The rhetoric of objects reflects not only the roles that men and women play within their society or expressions of "part-time (male-female) cohabitation", it also reflects the group's values and lifestyle, and in the case of the Moroccan weddings, tribal affiliation as well. ${ }^{23}$

Analyzing rituals leads some researchers to focus on one object in particular: bridal gowns in France ${ }^{24}$ or women's waistbands in Slavic and Maghrebin countries. ${ }^{25}$ These ritual trappings evoke, or even incarnate the identity of the young women who wear them - an identity being created: wives and mothers, an identity that must be maintained over time, sometimes by preserving vestiges of the ritual. These approaches to rituals are not particularly innovative; their value resides in the fact that they remind us that studying these symbolic logics is meaningless unless they are rooted in social logic. It becomes clear why so many studies correlate the two dimensions.

\footnotetext{
22 Monjaret \& Pugeault 2012.

23 Gélard 2012.

24 Cicchelli-Pugeault 2000.

25 Benfoughal 2013.
} 


\section{Technification: producing and cultivating the sexes in daily life}

If ritual-related-objects have a sex, then what about the objects used in everyday life? Once again, the question is not new in and of itself: the study of material culture has allowed ethnologists, and others, to shed light on the ways in which the separation of the sexes has been formalized in the most everyday chores, and thus to discern gendered and social hierarchies. It would seem that technology plays a nonnegligible role in that process. Therefore, in this survey, I will use the term "technification" to refer to the process - the action - that consists in producing and transforming both objects and bodies through technical practices. In this way, social and material "doing" and "being" are revealed. Objects become associated with bodies; bodies are taken over by objects. A number of studies show how male and female bodies are shaped by technology, that objects become gendered through practices. So what does that say about the borders between genders?

Certain anthropologists are trying to answer that question by questioning the a priori dominant gendered order, which divides the world in two. The work of both Christian Bromberger ${ }^{26}$ - on ricegrowing activities in Iran - and Béatrice Lecestre-Rollier, ${ }^{27}$ in the Moroccan High Atlas, fits into that perspective. Although they work in different areas, both of these anthropologists point out that in certain contexts, and for certain activities, a certain "tolerance," or "porosity" in how tasks and objects are assigned can ignore the usual norms, although those norms are still influential. Christian Bromberger points out that, if no other help was available, "farmers somewhat shame-facedly admitted that they had to lend a hand" for tasks that are normally considered women's work. ${ }^{28}$ This feature seems to transcend cultural areas. It would seem to be easier for a woman to adopt male activities, and, therefore, to handle the tools required, than the other way around. According to the author, in the case that he studied, we are essentially dealing with an "asymmetrical complementarity," as women are still over-exploited. Arrangements

\footnotetext{
26 Bromberger 2012.

27 Lecestre-Rollier 2012.

28 Bromberger 2012: 45.
} 
between the sexes do, therefore, exist. As Béatrice Lecestre-Rollier explains, "the gendered borders separating activities, technologies and objects $(. .$.$) are constantly being crossed or moved, depending on all$ sorts of changes in circumstances", ${ }^{29}$ as well as changes in technology and technical innovation. This porosity could lead one to suppose the existence of practices and objects that are "transgender" or that are associated with "humans in general", as Martine Segalen suggests in the framework of her reflections about spoons. ${ }^{30}$ Based on those studies, however, we seem to be witnessing more of a shifting of the cursor delineating the border than an erasure of the border itself, which suggests the flexibility of the idea of gender, and of genders.

Gendered identities don't dissolve so easily; they are firmly anchored in the materiality of things, they are formulated in contact with objects: both those that are being made and those that are associated with a given technology. They play with and off of the technology, its tools and its products. Once again, the focus seems to be placed more regularly on female issues, male ones only appear as an echo or negative. One has to wonder if ethnologists still tend to see the materiality of "ordinary items" as belonging more to women's sphere than to men's, to the domestic sphere rather than the public one, thereby reproducing the classical schema of separating the sexes and of a gendered division of spaces and the activities which that separation leads to.

Women's fate is achieved by doing. Doing is thus their being. The anthropologist Myriem Naji identifies that perfectly, taking the example of weaving done by women living in a region of southern Morocco. ${ }^{31}$ The creation of their identity depends on the intertwined shaping of both the weaving and of their bodies, a co-production. The physical experience of working on the fabric both affects and transforms the person; technical worth and moral worth strike a balance, the object and the emerging subject are intertwined. According to this author, the concept of subjectification takes on its full meaning here. ${ }^{32}$ In an

\footnotetext{
29 Lecestre-Rollier 2012: 202.

30 Segalen 2012.

31 Naji 2009.

32 Naji 2009.
} 
entirely different geographical context, the anthropologist Annabelle Vallard proposes a similar interpretation of the Laotian tube skirt. ${ }^{33}$ She focuses on the reification process of the feminine ideal. Even though the skirts are no longer physically produced by women, young or old, they still reflect values and morals in both an intimate and a political dimension. In that sense, their "polysemic reality" is not unlike that of the Muslim veil, ${ }^{34}$ even though, in most representations, the latter is associated with a religious dimension.

Articles of clothing or jewelry furnish elements of reflection about the social construction of femininity; that is undoubtedly why so many researchers focalize on one specific item: skirts, ${ }^{35}$ veils, ${ }^{36}$ belts, ${ }^{37}$ bras, ${ }^{38}$ items of jewelry ${ }^{39}$ or handbags. ${ }^{40}$ Rather than go into detail for each study, suffice to say that they all address these objects as symbols incarnating specific parts of women's bodies. They show up in both everyday and ritual activities. The feminine construct is devised in the play of appearances, in codes and objects that are acquired gradually and transmitted from one generation to the next. Pearl necklaces, for instance, as the reminder of a destiny, was studied by the ethnologist Patrizia Ciambelli. ${ }^{41}$

While objects more often act as markers of gender and age, they can also be markers of social class. Some very recent research into work clothes confirms their gendered and social dimension. ${ }^{42}$ Anne Monjaret sees overalls as the symbol of the male "worker's body", while acknowledging that women were quick to adopt it. Wearing work clothes produces a body and attitudes. Producing an item of clothing, as was seen above, leads to a co-production of the item and the body

\footnotetext{
33 Vallard 2012.

34 Sanna 2013.

35 Vallard 2012.

36 Sanna 2013; Zeljkovic 2013.

37 Benfoughal 2013.

38 Gallot 2013.

39 Ciambelli 2012.

40 Jean-Claude Kaufmann devotes part of his book about handbags to "men with handbags". Kaufmann 2011: 208-214.

41 Ciambelli 2012.

42 Monjaret 2012; Hersant \& Le Tirant 2013.
} 
that works on it. The example developed by the historian Fanny Gallot about seamstresses who produce lingerie, and are therefore both producers and consumers of bras, is particularly relevant in those terms. ${ }^{43}$ In our consumer society, the question of gender and objects cannot be separated from the question of their merchandization.

\section{Merchandization: objects of every desire}

The dynamic of the gendering or even sexualization of objects should not be dissociated from economics. Some studies have focused on making this principle explicit, starting with those which examine the gendered dimension of money. Money, it would seem, has a sex, or to be more precise, the ways in which it is used seem to have one: that is the thesis of the anthropologist Isabelle Guérin. ${ }^{44}$ These socially and culturally differentiated uses require us to reassess certain presuppositions concerning money: its neutrality, anonymity, etc.

The worlds of merchandise are not exempt from this genderbased logic either. Toys, as the work ${ }^{45}$ of the sociologist Mona Zegai demonstrates - including the catalogues that present them, the shelf space devoted to them, and the advertisements that promote them generally reproduce the classic model of the gendered division of activities. The Christmas gifts studied by the sociologist and ethnologist Martyne Perrot are no exception. ${ }^{46}$ Indeed, when distributors allow themselves to take a few liberties on this subject, blurring the conventional boundaries, they run the risk of exposing themselves to social ire: that was the case in 2013 when the " $U$ " supermarket chain's Christmas catalogue featured boys pushing dolls' prams, girls with cars, and everyone having fun in the kitchen together. Nevertheless, these initiatives remain isolated. According to the historian Florence Rochefort, toys are as yet nowhere near having lost their sexist connotations. ${ }^{47}$

\footnotetext{
43 Gallot 2013.

44 Guerin 2002.

45 Zegaï $2010 \mathrm{a}$ and $\mathrm{b}$.

46 Perrot 2013.

47 Rochefort 2013.
} 
In order to reach their target and to sell, manufacturers and advertising agencies conform to the dominant norms and stereotypes that see women as objects, specifically as sexualized objects. Signboards belonging to the City of Paris recently featured a poster that poked fun at that concept. Having won first prize in the ÉgalitéE ("Shequality") 2014 competition, this poster showed a red water bottle (gourde in French, which is also a slang term for an empty-headed woman) with the word gourde printed on it in black lettering. Beneath it was the sentence, "Ceci n'est pas une femme", in reference to Magritte's famous painting "Ceci n'est pas une pipe" and to the 1973 text of the same name in which Michel Foucault proposes thoughts on the representation of objects. Women's bodies, when displayed, become objects. The nude advertising calendars that Anne Monjaret analyses are perfect examples of this. While women have long been undressed for commercial purposes - sex sells - men have started undressing themselves, in an act that can take on the political dimension of claiming the right to do so, which women have occasionally appropriated as well ${ }^{48}$ - nudity gets people talking. While social reality allows us to emphasize the plurality of meanings of these calendars as gendered objects, we can all agree that their sexy side, and even more undoubtedly, their sexual side, are clearly present. This type of nude calendar is a sexually marked object, one that participates in the "economy of obscenity", in the same way that dildos do, as the sociologist Baptiste Coulmont has pointed out. ${ }^{49}$ Objects related to sexuality have a marketplace. Sex itself - and, therefore, the body - is merchandise that is bought, sold and bargained over. ${ }^{50}$

\section{Museumification:}

\section{the consecration of a gendered material heritage}

Gender is represented, learned, ritualized, manufactured, sold and exposed through objects. "Matter for thought", the gendering and sexualization of objects, or, in other words, the materialization of

\footnotetext{
48 Monjaret 2006.

49 Coulmont 2012.

50 Combessie \& Mayer 2013.
} 
gender, brings about the conditions for the preservation and scenography of the artefacts themselves.

Everyday objects are collected according to sexual affinities, anthropologist Bjarne Rogan explains. Women are the curators of home and family, while men curate society, and their collections "are often the basis for our museums". ${ }^{51}$ Thus objects that bear witness to our societies have entered and continue to enter museums.

The collections housed in ethnographic museums often include the most ordinary objects: school uniform smocks, ${ }^{52}$ spoons, ${ }^{53}$ etc. are exhibited in ways that respect the separation of the sexes, but in museographical terms, the demonstration on the subject of gender is generally implicit rather than explicit. ${ }^{54}$ In fact, Federica Tamarozzi expresses surprise at how under-represented in public collections are toys and packaging from a period in which boys and girls were encouraged to play together. ${ }^{55}$ Nowadays, the discourse is changing. Exhibits investigate gender, and display different ways of representing bodies: masculine, feminine or sometimes a combination of the two. In the "Morceaux exquis" 56 exhibit, alongside figurations of feminine and masculine attributes like breasts ${ }^{57}$ or phalluses, ${ }^{58}$ one can also find objects that have both identities at once. Examples include an English doll in the MuCEM's collection - its distinguishing characteristic is to be "two-sided: girl/boy"59 - and a Portuguese wine carafe with phallusshaped neck and a vagina-shaped base. ${ }^{60}$ Other objects that are less explicit for those who are not trained at decoding their symbolism are also on display, like "Catherinette" 61 hats or hairpins, attributes of

\footnotetext{
51 Rogan 2012: 32.

52 Anstett 2012.

53 Segalen 2012.

54 Chevallier 2013.

55 Tamarozzi 2012.

56 Boëtsch \& Tamarozzi 2011.

57 Chevé 2011.

58 Bardiès-Fronty 2011.

59 Boëtsch \& Tamarozzi 2011: 15.

60 Abriol 2011.

61 Translator's note: traditionally, on St Catherine's Day in France, unmarried women aged 25 and up wore special hats and were known as Catherinettes. The
} 
unmarried women and marital reminders. Their terminology crops up in everyday practices, rituals and even in tales and legends. ${ }^{62}$

But one of the inaugural exhibits at MuCEM (the Museum of European and Mediterranean Civilizations), "Au bazar du genre, Féminin/masculin en Méditerranée" ("At the Gender Bazaar: Feminine/Masculine in the Mediterranean") focused more explicitly on this social issue. ${ }^{63}$ As well as leading to a new interpretation of existing collections through the prism of gender, it also contributed to new ones entering the museum's permanent collection, and, in response, to making a place for works by contemporary artists who transgress their society's norms. ${ }^{64}$ The objects belong to a curatorial narrative that invites us to (re)consider both their gender, and gender more generally.

In conclusion, it can be stated with little risk of error that for over ten years now, French-language ethnologists and sociologists' reflections on the correlations between gender and material culture are still too rare, and are more likely to be focused on women and children - men being conspicuously absent. Nevertheless, the French papers that were skimmed through for this article do show a will to pursue analyses of the social construction of gendered identities and of the sex-based social relationships that are expressed through them, while considering more precisely the porosity of the borders between the feminine and the masculine. What these analyses contribute in terms of the gendering and sexualization of objects and practices is directly related to the proposed deconstruction of stereotypes, and to shedding light on the pluralities of expression of the human species; they do not let us forget the eminently political dimension being played out in this material manufacture of gender: gender is never neutral, gender is plural...

Translated by Regan KRAMER

tradition has been maintained in some provinces and amongst dressmakers and milliners in Paris.

62 Monjaret 2005.

63 See the interview with Denis Chevallier about the exhibition in this issue of Clio.

64 Chevallier et al. 2013. 


\section{Bibliography}

ABriol, Stéphane. 2011. Pichet. In Morceaux Exquis : le corps dans les cultures populaires, ed. Gilles BOËTSCH and Federica TAMAROZZI, 154-155. Paris: CNRS Éditions.

ANSTETT, Élisabeth. 2012. De la série au modèle: uniforme scolaire féminin et identité sexuée dans la Russie des années 80. In Les Objets ont-ils un genre? Culture matérielle et production sociale des identités sexuées, ed. Élisabeth ANSTETT and MarieLuce GÉLARD, 121-135. Paris: Armand Colin, coll. "Recherches".

AnSTETT, Élisabeth, and Marie-Luce GÉLARD (eds). 2012. Les Objets ont-ils un genre? Culture matérielle et production sociale des identités sexuées. Paris: Armand Colin, coll. "Recherches".

BARDiÈs-Fronty, Isabelle. 2011. Phallus. In Morceaux Exquis : le corps dans les cultures populaires, ed. Gilles Bö̈TSCH and Federica TAMAROZZI, 146-153. Paris: CNRS Éditions.

Benfoughal, Tatiana. 2013. Symboliques de la ceinture féminine dans les représentations slaves et maghrébines. In Au Bazar du genre. Féminin/masculin en Méditerranée, ed. Denis Chevallier, Michel Bozon, Michelle Perrot and Florence Rochefort, 58-61. Paris: MuCEM, Éditions Textuel.

Bö̈tsch, Gilles, and Federica TAmarozzi (eds) 2011. Morceaux Exquis : le corps dans les cultures populaires. Paris: CNRS Éditions.

Bromberger, Christian. 2012. Masculin et féminin aux champs: les outils et le corps dans la riziculture du Gilân - Iran septentrional. In Les Objets ont-ils un genre? Culture matérielle et production sociale des identités sexuées, ed. Élisabeth ANSTETT and Marie-Luce GÉLARD, 35-46. Paris: Armand Colin, coll. "Recherches".

Chevallier, Denis. 2013. Le genre exposé au musée des Civilisations. In Au Bazar du genre. Féminin/masculin en Méditerranée, ed. Denis Chevaldier, Michel Bozon, Michelle Perrot and Florence Rochefort, 18-29. Paris: MuCEM, Éditions Textuel.

Chevallier, Denis, Bozon, Michel, Perrot, Michelle, and Florence Rochefort (eds) 2013. Au Bazar du genre: féminin/masculin en Méditerranée. Paris: MuCEM, Éditions Textuel.

Chevé, Dominique. 2011. Seins et gorge. In Morceaux Exquis : le corps dans les cultures populaires, ed. Gilles Bö̈TSCH and Federica TAMAROZZI, 114-121. Paris: CNRS Éditions.

Ciambelli, Patrizia. 2012. Colliers de perles : transmission, circulation, mémoire du féminin. Techniques \& Culture 59: 78-95. 
Cicchelli-Pugeault, Catherine. 2000. Le devenir des robes et des photographies de mariage. Dialogue 148: 21-35.

Combessie, Philippe, and Sylvie MAYER (eds). 2013. Sexualités négociées. Ethnologie française 3 .

Coulmont, Baptiste. 2012. Les économies de l'obscénité : circuits sexuels et sexués du godemiché. In Les Objets ont-ils un genre? Culture matérielle et production sociale des identités sexuées, ed. Élisabeth ANSTETT and Marie-Luce GÉLARD, 155-172. Paris: Armand Colin, coll. "Recherches".

Cresson, Geneviève. 2010. Indicible mais omniprésent: le genre dans les lieux d'accueil de la petite enfance. Cabiers du Genre 49(2) "Les objets de l'enfance": 15-33.

DELALANDE, Julie. 2001. La Cour de récréation: pour une anthropologie de l'enfance. Rennes: Presses universitaires de Rennes.

- 2003. La socialisation sexuée à l'école : l'univers des filles. La lettre de l'enfance et de l'adolescence. Revue du Grape 51 "Les filles": 69-75.

FAURE-ROUESNEL, Laurence. 2001. La feuille et le stylo : usages et significations des instruments scolaires. Ethnologie française 3: 503-510.

GALLOT, Fanny. 2013. La revanche du soutien-gorge: le corps des ouvrières de la lingerie (1968-2012). Clio. Femmes, Genre, Histoire 38 “Ouvrières, ouvriers”: 61-78.

GÉLARD, Marie-Luce. 2012. Le rôle des objets dans les rituels de mariage collectifs (Sahara, Maroc). In Les Objets ont-ils un genre? Culture matérielle et production sociale des identités sexuées, ed. Élisabeth ANSTETT and Marie-Luce GÉLARD, 89-103. Paris: Armand Colin, coll. "Recherches".

Guerin, Isabelle. 2002. Le sexe de la monnaie. Journal des anthropologues 90-91 "Monnaies: pluralités - contradictions" [on line].

GuilberT, Georges-Claude. 2014. Le Genre des objets. Paris: L'Harmattan, coll. "Questions contemporaines".

Hersant, Guy, and Dominique Le Tirant. 2013. Pose travail. Genk: Éditions Snoeck.

JONAS, Irène. 2010. La photographie de famille: une pratique sexuée? Cabiers du Genre 48(1): 173-191.

Julien, Marie-Pierre, and Céline Rosselin. 2005. Matière à genre. In La Culture matérielle, ed. Marie-Pierre Julien and Céline Rosselin, 92-95, Paris: La Découverte, coll. "Repères".

KaUfmann, Jean-Claude. 2011. Le Sac: un petit monde d'amour. Paris: J.C. Lattès.

LeCESTRE-Rollier, Béatrice. 2012. Dichotomie homme/femme ou porosité des genres? Activités, techniques et objets dans le Haut Atlas marocain. In Les Objets ont-ils un genre? Culture matérielle et production sociale des identités sexuées, ed. Élisabeth 
ANSTETT and Marie-Luce GÉLARD, 191-205. Paris: Armand Colin, coll. "Recherches".

Mardon, Aurélia. 2010. Construire son identité de fille et de garçon : pratiques et styles vestimentaires au collège. Cabiers du Genre 49(2) "Les objets de l'enfance": 133-154.

Monjaret, Anne. 2005. De l'épingle à l'aiguille: l'éducation des jeunes filles au fil des contes. L'Homme 173: 119-148.

- 2006. Les calendriers illustrés de nus féminins dans les espaces de travail masculins. In Oggetti e immagini: esperienze di ricerca etnoantropologica, ed. Federica TAmarozzi and Davide Porparato, 129-156. University of Eastern Piemont, Torino: Omega Édizioni.

— 2012. Le bleu de travail, une affaire d'hommes? Pratiques populaires autour d'un symbole ouvrier masculin. In Les Objets ont-ils un genre? Culture matérielle et production sociale des identités sexuées, ed. Élisabeth ANSTETT and Marie-Luce GÉLARD, 47-62. Paris: Armand Colin, coll. "Recherches".

Monjaret, Anne, and Catherine Pugeault. 2012. Enterrements de célibat, mariage et ordre familial: quand le mort saisit le vif. Recherches familiales 9 "Familles et rites": 9-20.

NAJI, Myriem. 2009. La formation de féminités à travers le tissage dans le Sirwa (Maroc). In Le Sujet contre les objets... tout contre, ed. Marie-Pierre JULIEN and Céline Rosselin, 179-193. Paris: Éditions du CTHS.

OCTOBRE, Sylvie. 2010. La socialisation culturelle sexuée des enfants au sein de la famille. Cabiers du Genre 49(2) "Les objets de l'enfance": 55-76.

PASQUier, Dominique. 2010. Culture sentimentale et jeux vidéo: le renforcement des identités de sexe. Ethnologie française 1: 93-100.

Perrot, Martyne. 2013. Le Cadeau de Noël: histoire d'une invention. Paris: Autrement, coll. "Leçons de choses".

QUÉRÉ, Louis, and Zbigniew SMOREDA (eds). 2000. Le sexe du téléphone. Réseaux 103.

ROCHEFORT, Florence. 2013. Contre les jouets sexistes. In Au Bazar du genre. Féminin/masculin en Méditerranée, ed. Denis Chevallier, Michel Bozon, Michelle PERrot and Florence RocheForT, 115-118. Paris: MuCEM, Éditions Textuel.

RoGAN, Bjarne. 2012. Objets de collection et modes de collectionner: à propos de la sexualisation des objets. In Les Objets ont-ils un genre? Culture matérielle et production sociale des identités sexuées, ed. Élisabeth ANSTETT and Marie-Luce GÉLARD, 17-34. Paris: Armand Colin, coll. "Recherches". 
Ruel-TRAQuet, Sophie. 2010. Filles et garçons : loisirs culturels et différenciation de genre dans l'enfance. In the [on line] proceedings of the Enfance et cultures : regards des sciences humaines et sociales, ed. Sylvie OCTOBRE and Régine SirOTA. http://www.enfanceetcultures.culture.gouv.fr/actes/rueltraquet.pdf.

SANNA, Maria Eleonora. 2013. Voiles musulmans: une réalité polysémique. In $A u$ Bazar du genre. Féminin/masculin en Méditerranée, ed. Denis Chevallier, Michel Bozon, Michelle Perrot and Florence Rochefort, 192-197. Paris: MuCEM, Éditions Textuel.

SEGALEN, Martine. 2012. Les cuillères, un genre humain? In Les Objets ont-ils un genre? Culture matérielle et production sociale des identités sexuées, ed. Élisabeth ANSTETT and Marie-Luce GÉLARD, 175-190. Paris: Armand Colin, coll. "Recherches".

TABET, Paola. 1979. Les Mains, les outils, les armes. L'Homme 19(3-4) “Les catégories de sexe en anthropologie sociale": 5-61.

TAmarozZI, Federica. 2012. Manger son enfance : les jouets Habert et le Manuel de Nonna Papera dans l'Italie des années 1960-1980. In Les Objets ont-ils un genre? Culture matérielle et production sociale des identités sexuées, ed. Élisabeth ANSTETT and Marie-Luce GÉLARD, 223-241. Paris: Armand Colin, coll. "Recherches".

VALlard, Annabelle. 2012. De la jupe à la femme: tissage, vêtements et subjectivation au Laos. In Les Objets ont-ils un genre? Culture matérielle et production sociale des identités sexuées, ed. Élisabeth ANSTETT and Marie-Luce GÉLARD, 105120. Paris: Armand Colin, coll. "Recherches".

ZEGAÏ, Mona. 2010a. La mise en scène de la différence des sexes dans les jouets et leurs espaces de commercialisation. Cabiers du Genre 49(2) "Les objets de l'enfance": 35-54.

- 2010b. Trente ans de catalogues de jouets: mouvances et permanences des catégories de genre. In the [on line] proceedings of the Enfance et cultures : regards des sciences bumaines et sociales, ed. Sylvie OCTOBRE and Régine Sirota http://www.enfanceetcultures.culture.gouv.fr/actes/zegai.pdf.

ZELJKOviC, Ljijana. 2013. Le voile à Sarajevo. In Les Objets ont-ils un genre? Culture matérielle et production sociale des identités sexuées, ed. Élisabeth ANSTETT and MarieLuce GÉLARD, 202-203. Paris: Armand Colin, coll. "Recherches". 